\title{
Identification Spatial Effects of Space Economy in Peripheral Areas of Sanandaj
}

\author{
Atefe Ahmadi \\ Ph.D. Scholar, Geography and Rural Planning, Kharazmi University, Tehran, Iran \\ Hassan Afrakhteh \\ Professor, Geography and Rural Planning, Kharazmi University, Tehran, Iran \\ Mohammad Taghi Rahnamee \\ Professor, Geography and Urban Planning, Tehran University, Tehran, Iran \\ Hamed Ghadermazi \\ Asst. Professor, Geography and Rural Planning, Khurdistan University, Khurdistan, Iran
}

\begin{abstract}
Areas around cities are crystallization space organization with natural, social, economic and physical revelation in geographic context to another that inform in context of dynamic interaction of human and environment within economical and social system. In capitalism organizations space formation in order to goals of circulation and accumulation capital and in finally adapted to administrative and political structure and economic base each geographical place in priorities of accumulation of capital will form forms, structure and functions of different. The type of this research is descriptive-analytical and is based on the process of combining multiple methods. Therefore, this research attempt to evaluate the spatial effects of space economy revolution in the peripheral areas of Sanandaj. In this regard, It were identified criteria for space economy revolution in four dimensions social, economic, physical - environmental and infrastructure to identify the most important spatial effects of space economy revolution in the study area, with using multi - criteria decision analysis methods FTOPSIS in each dimension have been recognized. The results show that of the most important spatial effects of Space Economy Revolution in the economic sector include rising land prices, buying and selling land for farming and gardening, reduction in the area under cultivation, increased investment in real estate sector (buy and sell housing). The most important social effects of Space Economy Revolution in social dimension are rural population growth, increasing rural - urban migration and most important physical - environmental effects of Space Economy Revolution in the peripheral villages of Sanandaj include garden and agricultural land conversion to second home, destruction of natural landscapes of villages, and the spread of illegal construction. And in the infrastructure facilities and services dimension, the effects of Space Economy Revolution in the peripheral villages of Sanandaj include improving infrastructure of services, improving access to communication services and development of financial services such as Post Bank and Corporations.
\end{abstract}

Key words: $\quad$ SPACE ECONOMY, REVOLUTION, SPATIAL EFFECTS, SANANDAJ CITY

\section{Introduction}

Space is actually an objectivity resulting from mutual interactions of individuals and human groups in a place, or in other words, it is the consequence of interactive functions of two natural - ecological and socio - economic environments. Space can thus be considered as a kind of social production in a place. Since space is composed of related components, it could be regarded as a system and because this system is a spatial reality, so one can speak of spatial system. The study of space is always accomplished on the basis of a certain scale, including large - scale space (global, country or regional), medium scale (regional, local, urban and rural), or small scale (village, farm, neighborhood, etc systems...) (Saedi, 2009).

In order to understand space revolution, it is essential to understand several factors affecting space organizing and production. Space economy revolutions are influenced by a variety of factors at the national, regional and local level, which lead to the formation of different special effects in different geographical areas. 


\section{Yinternational Research Journa}

p-ISSN 2202-2821 e-ISSN 1839-6518 (Australian ISSN Agency)

In recent years, as a results of rural - urban migrations (and vice versa over the last decade), metropolitan and urban areas in Iran have experienced incomplete and undeveloped urbanization resulting from oil capitalism (Saedi \& Hosaini, 2007: 71-90). In most cases, the level and scope of uncontrolled urban growth have caused considerable concerns among experts and informed citizens.

It is obvious that uncontrolled urban growth and encroaching on the lands of peripheral villages, that give rise to significant changes in functional and space economy revolutions of the rural space result from diverse a phenomenon which is traceable by a correlated chain of events.

In the systems, which their political and economic decisions to achieve specific goals rely on oil revenues, much space economy revolution in peripheral villages is traceable from national to regional level and finally at the local level or it returns to the fundamental backgrounds and its related trends. In this regard, the present study is to investigate the factors influencing space economy revolution and also its spatial effects in different aspects. The most important spatial effect in the study area will be recognized.

\section{TEHORETICAL FOUNDATIONS}

Space economy, spatial pattern of the economy (such as its distribution and location of its constituent activities) and the spatial flows between them such as population, goods, services and capital movements is called space economy (Afrakhteh, 2012) (Figure 1). In the capitalist systems, the concepts of space and its various applications is different. According to Marx, in a capitalist system space is a part of the production forces, which is placed alongside other production factors (knowledge, skills, labor, raw materials, technology, etc,...).

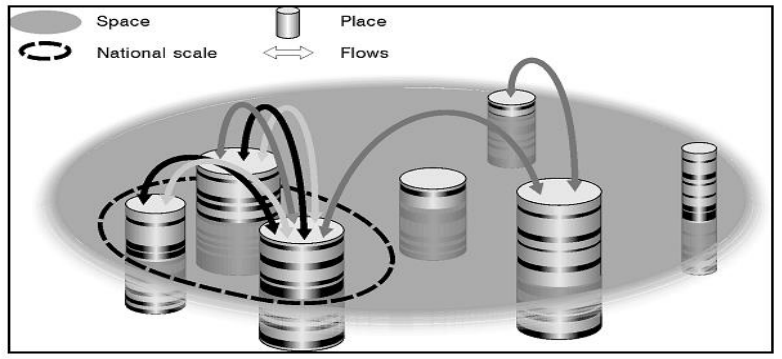

Figure 1: The Space and spatial flows

According to Cohen, the role of space as a production force, and thus as a fundamental element in capitalist mode of operation should be examined, and in such circumstances, of course, space property can provide an important position in the economic structure and create a specific space structures and forms (Cohen, 1978: 51). This can not only encompass specific economic sectors and dimensions, but also the totality
Vol. 06 No. 022016

82800602201602

of social spaces of human settlements. Because the special relations of capitalism embrace not only the plans and organizing production spaces, such as factories, workshops, and other activity centers, but also it encompasses spatial organization and differentiation the totality of urban space.

Therefore, the main philosophy of the capitalist systems, production and reproduction of space is based on the production and capital accumulation (production for production and accumulation for accumulation), which has tremendous impact on production and the organization of space. Therefore, in this system; space is the product of social relations and is organized within the framework of the political and economic relations (Ahmadi, 2017: 55).

The space can thus be considered as a form of social production in a place, and because space consists of connected components, it can be regarded as a system, and because this system is a spatial reality, one can speak of spatial system. The study and recognition of space is always accomplished on the basis of a certain scale, including large - scale space (global, country or regional), medium scale (regional, local, urban and rural), or small -scale (village, farm, neighborhood, systems, etc.) (Saedi, 2008).

The important aspect of the study of space and its development is conducted in the regional scale, where rural urban relations are of the most important trends affecting the formation of regional spaces. The regional spaces are undergoing a fundamental changes and transformations resulting from the passage of time, the process of rationalization, and changes in people's livelihood, population growth, the use of technology, socio - economic programs and policies of governments in attention or inattention to any of these population centers (Nazarian, 2009: 210).

In order to understand space revolution, it is necessary to recognize the dominant ideology of planning, in its various dimensions, which is influential in organizing the space and production of space. Revolutions contributing space economy are influenced by different approaches, which has been developed and implemented in different time periods.

Planning is undoubtedly considered as a political activity, which stems from the dominant ideology of the society. During planning, planners apply different concepts of the public interests. They are always under pressure from government agencies or interest groups. Therefore, the geographical landscapes, which appear in the living space at the end stages of planning, are a symbol of the dominant political ideology of the society.

Therefore, planning in different ideologies creates different geographical features, and these different geographical 


\section{Yinternational Research Journa!}

p-ISSN 2202-2821 e-ISSN 1839-6518 (Australian ISSN Agency)

features represent the share and the role of interests in political ideology (Shokuie, 2003: 50). The political economy of the space is one of the new topics for dealing with this situation. According to geographers not only form and physical qualities are important in the process of space production, but also perceptions, beliefs, opinions, ideologies, cultural characteristics, level of awareness, the way of thinking, political economy, and cultural systems play effective role.

The political economy of space has a strong connection with different economic and social systems and thus each one of the liberal, conservative, radical and .... Systems have special effects of political economy on urban and rural spaces. It should be noted that dominant political economy of each region is not the only factor, but it is one of the determining factors in creating space. Thus, political economy is considered as an independent variable for space formation that has been proposed as a dependent variable, too (Piran, 1991: 70).

As mentioned before, planning by itself is a political activity that stem from the dominant ideology of the society, depending on the prevailing economic thinking is influenced by what schools and ideologies, space formation would be accepts different effects. So the dominant economic thinking in planning, which affects the shape of space formation represents the political economy of space. Accordingly, different socio - economic systems with their own ideology create geographically diverse landscapes.

In the capitalist systems, the purpose of space production is capital circulation and accumulation. In such circumstances, the economic and political structure of societies and the methods of decision making by governments to achieve this goal lead to space economy revolutions, and finally, in accordance with the political and administrative structure of different societies and the economic base of each location for capital accumulation priorities will be formed new forms, structures and functions (Figure 2).

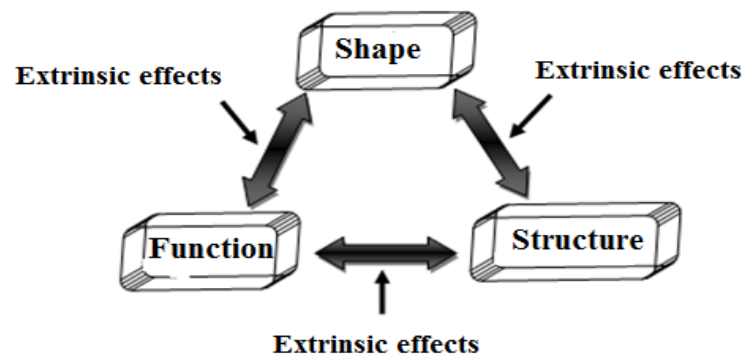

Figure 2: The main element of space, Source: (Ahmadi, 2017)
Vol. 06 No. 022016

82800602201602

\section{CASE STUDY}

The study area of this research is the surrounding villages of Sanandaj City in Kurdistan Province (fig: 3). Kurdistan Province is hugged by the foothills of the Zagros Mountains and more than 82 percent of its area is mountainous. Consequently, 77 percent of rural settlements are located in mountainous areas (Statistical Center of Iran, 2007: 65).

Sanandaj city of Kurdistan province with an area of 2,906 square kilometers locates between 35 degrees and 1 minute to 35 degrees and 32 minutes of north latitude and 46 degrees and 18 minutes to 47 degrees and 16 minutes of east longitude from prime meridian and places in an average height above sea level in Kurdistan region in Zagros Mountains in central front bowed to southern province (Ahmadi et all, 2011: 6). The study area in this research is 22 villages including (Asaoleh, Salavat Abad, Doshan, Ghar, Gholian, Babariz, Dolat Abad, Khalichan, Barazan, Karjo, Killaneh, Dadaneh, Kani Meshkan, Karahsi, Anbarbazan, Khoshkavel, Serenjyaneh Sofla, Serenjyaneh Olia, Arandan, Navareh, Sorkheh Dezaj, Ajgarah, Sofian) surrounded Sanandaj City.

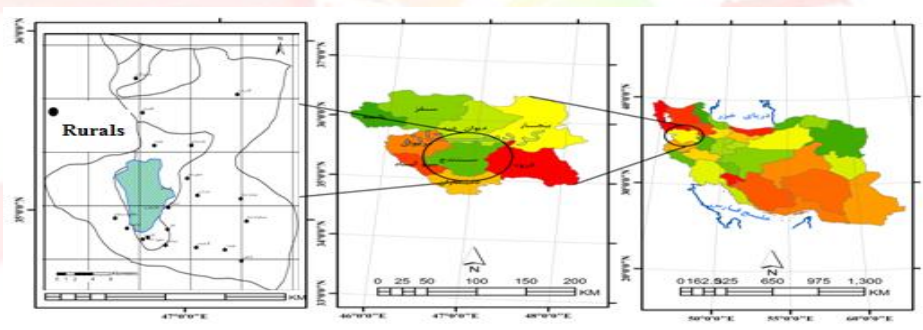

Figure 3: Peripheral areas Sanandaj

\section{PROCEDURE}

The type of this research is descriptive-analytical and is based on the process of combining multiple methods. Therefore, in this study to evaluate the space effects of space economy revolution in the peripheral areas of Sanandaj, first of all, necessary criteria of four dimensions of social, economic, physical and infrastructure were identified (Table 1,2).

Accordingly, in the current study in order to operationalize the methodology was designed a questionnaire using the recognized criteria and distributed in the 25 peripheral villages of Sanandaj City in the summer of 2016, among the Village Assistance Bureaus (VAB), Rural Islamic Council.

The study population consisted of 50 people (employees of Rural Islamic Council and Village Assistance which in general, 96 samples, 2 people from Rural Islamic Council and 2 people from Village Assistance of each village were selected. 
Table 1 : The Spatial Effects of Space Economy

\begin{tabular}{|c|c|c|c|}
\hline \multicolumn{4}{|c|}{ Economic Dimension of the Spatial Effects } \\
\hline E10 & $\begin{array}{l}\text { Increased employment } \\
\text { opportunities in service } \\
\text { sector }\end{array}$ & $\mathrm{E} 1$ & $\begin{array}{l}\text { Increased investment in } \\
\text { infrastructure }\end{array}$ \\
\hline E11 & $\begin{array}{c}\text { Increased employment } \\
\text { opportunities in agriculture }\end{array}$ & E2 & $\begin{array}{l}\text { Increased investment in buy and } \\
\text { sell housing }\end{array}$ \\
\hline E12 & $\begin{array}{c}\text { Increased revenue from } \\
\text { service sector activity than } \\
\text { other activities }\end{array}$ & E3 & Increased investment in industry \\
\hline E13 & $\begin{array}{l}\text { Income inequality between } \\
\text { residents }\end{array}$ & E4 & $\begin{array}{l}\text { Increased investment in } \\
\text { productive and entrepreneurial } \\
\text { services }\end{array}$ \\
\hline E14 & $\begin{array}{c}\text { Reduction of employees in } \\
\text { agriculture sector }\end{array}$ & E5 & $\begin{array}{c}\text { Increased investment in } \\
\text { agriculture }\end{array}$ \\
\hline E15 & $\begin{array}{l}\text { Increased prices of goods } \\
\text { and services }\end{array}$ & E6 & $\begin{array}{l}\text { Increased investment in the } \\
\text { livestock industry (cattle farming } \\
\& \text { animal husbandry) }\end{array}$ \\
\hline E16 & $\begin{array}{l}\text { Reduction in the area under } \\
\text { cultivation }\end{array}$ & E7 & $\begin{array}{l}\text { Buying and selling land for } \\
\text { farming and gardening }\end{array}$ \\
\hline E17 & Rising land prices & E8 & Increased revenue \\
\hline E18 & $\begin{array}{l}\text { Seasonal incomes of rural } \\
\text { households }\end{array}$ & E9 & $\begin{array}{l}\text { Increased employment } \\
\text { opportunities in industrial sector }\end{array}$ \\
\hline
\end{tabular}

Table 2: The Spatial Effects of Space Economy

\begin{tabular}{|c|c|c|c|}
\hline \multicolumn{2}{|c|}{$\begin{array}{c}\text { Spatial Effects in the Physical and } \\
\text { environmental Dimension }\end{array}$} & \multicolumn{2}{|c|}{$\begin{array}{c}\text { Spatial Effects in the Social } \\
\text { Dimension }\end{array}$} \\
\hline E34 & $\begin{array}{c}\text { Housing improvement } \\
\text { (improvement in home } \\
\text { appliances, improve housing } \\
\text { quality and ...) }\end{array}$ & E19 & Rural population growth \\
\hline E35 & Improving transport facilities & E20 & $\begin{array}{l}\text { Employment of women and } \\
\text { children }\end{array}$ \\
\hline E36 & $\begin{array}{c}\text { Improving infrastructure of } \\
\text { services }\end{array}$ & $\begin{array}{l}\text { E21 } \\
\text { E22 }\end{array}$ & $\begin{array}{l}\text { Increased urban - rural } \\
\text { migration and travel }\end{array}$ \\
\hline E37 & $\begin{array}{c}\text { Improving access to } \\
\text { communication services } \\
(\text { telephones, ...) }\end{array}$ & & \\
\hline E38 & $\begin{array}{l}\text { Development of roads' } \\
\text { infrastructures }\end{array}$ & E23 & $\begin{array}{c}\text { Increased participation in the } \\
\text { development and renewal }\end{array}$ \\
\hline E39 & $\begin{array}{c}\text { Development of financial } \\
\text { services such as Post Bank and } \\
\text { Corporations }\end{array}$ & E24 & $\begin{array}{l}\text { Improving educational } \\
\text { facilities }\end{array}$ \\
\hline E40 & $\begin{array}{l}\text { Expansion of investment in } \\
\text { water transfer projects to the } \\
\text { farms and gardens }\end{array}$ & E25 & Improving health facilities \\
\hline \multicolumn{4}{|c|}{ Spatial Effects in the Infrastructure Dimension (services and manufacturing) } \\
\hline E26 & \multicolumn{3}{|c|}{ Destruction of natural landscapes of villages } \\
\hline E27 & \multicolumn{3}{|c|}{ Garden and agricultural land conversion to second home } \\
\hline E28 & \multicolumn{3}{|c|}{ Infrastructure development } \\
\hline E29 & \multicolumn{3}{|c|}{ Housing reconstruction } \\
\hline E30 & \multicolumn{3}{|c|}{ Rehabilitation and development of network of connection paths } \\
\hline E31 & \multicolumn{3}{|c|}{ The spread of illegal construction } \\
\hline E32 & \multicolumn{3}{|c|}{ Encroaching on rural natural resources } \\
\hline E33 & \multicolumn{3}{|c|}{ Rural environment pollution } \\
\hline
\end{tabular}

In order to identify the most important spatial implications and effects, space economy revolution in the study area, using multi - criteria decision analysis methods FTOPSIS, the spatial effects in each dimension have been recognized. Details will be presented in the following.

Fuzzy TOPSIS model was first presented by Chen \& Hwang to make decision on "n" criterion and "m" option. This model contains several stages to analyze data. The first step is creating decision matrix, which has been shown as in equation (1).

$$
\tilde{A}=\left[\begin{array}{cccc}
\tilde{x}_{11} & \tilde{x}_{12} & \ldots & \tilde{x}_{1 n} \\
\tilde{x}_{21} & \tilde{x}_{22} & \ldots & \tilde{x}_{2 n} \\
\ldots & \ldots & \ldots & \ldots \\
\tilde{x}_{m 1} & \tilde{x}_{m 2} & \ldots & \tilde{x}_{m n}
\end{array}\right] \text { Equation (1) }
$$

In this technique, if triangular fuzzy numbers are used for analyzing data, the performance will be as $\tilde{x}_{i j}\left(a_{i j}, b_{i j}, c_{i j}\right)$.

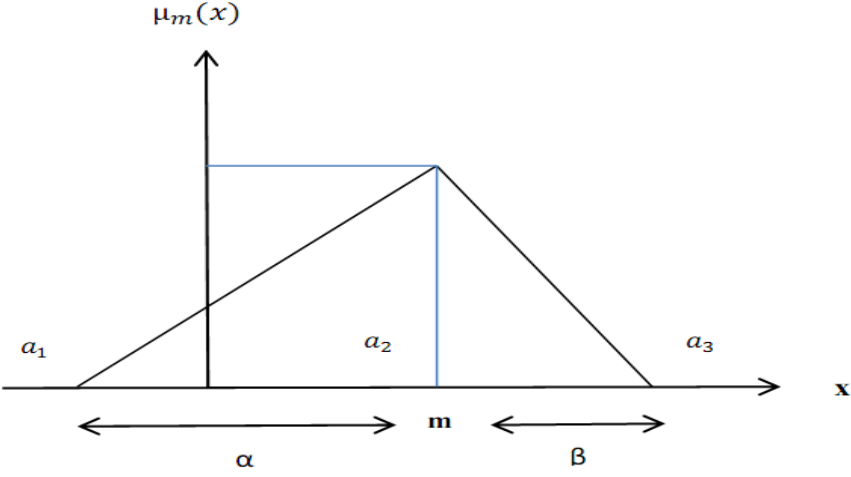

Figure 4: Membership function of fuzzy numbers in fuzzy environment

Meanwhile, in order to classify research indicators in the research technique framework, fuzzy verbal variables have been used in the form of triangular numbers as shown in the table 3:

Table3 : Verbal variables for analyzing importance of research indicators

\begin{tabular}{|c|c|c|}
\hline Fuzzy number & ID & $\begin{array}{c}\text { Importance of } \\
\text { indicator }\end{array}$ \\
\hline$(1,1,3)$ & $\mathrm{VP}$ & Very Poor \\
\hline$(1,3,5)$ & $\mathrm{P}$ & Poor \\
\hline$(3,5,7)$ & $\mathrm{M}$ & Medium \\
\hline$(5,7,9)$ & $\mathrm{G}$ & Good \\
\hline$(7,9,9)$ & $\mathrm{VG}$ & Very Good \\
\hline
\end{tabular}

In the second step, weight matrix of criteria is defined as specified in equation (2). 
$w_{j 1}=\min _{k}\left\{w_{j k 1}\right\}$

Equation (2)

$w_{j 2}=\frac{\sum_{k=1}^{k} w_{j k 2}}{k}$

$w_{j 3}=\max _{k}\left\{c_{j k 1}\right\}$

The third step is normalization of fuzzy decision matrix in which following equations are used:

$\tilde{r}_{i j}=\left[\frac{a_{i j}}{c_{j}^{*}}, \frac{b_{i j}}{c_{j}^{*}}, \frac{c_{i j}}{c_{j}^{*}}\right]$

$\tilde{r}_{i j}=\left[\frac{a_{j}^{-}}{c_{i j}}, \frac{a_{j}^{-}}{b_{i j}}, \frac{a_{j}^{-}}{c_{i j}}\right]$

Equation (3)

In these equations $c_{j}^{*}=\max _{i} c_{i j}$ and $a_{j}^{-}=\min _{i} a_{i j}$. Normalized fuzzy matrix $(\widetilde{R})$ would be as follows regarding the above equations:

$\left.\widetilde{R}=\tilde{r}_{i j}\right)_{m \times n} \mathrm{I}=1,2 \ldots, \mathrm{m} \quad$ Equation (4)

At the next stage, of the studied criteria positive and negative aspects of criteria are calculated. In this model, following equations have been used to calculated values given:

$\tilde{v}_{i j}=\tilde{r}_{i j}, \widetilde{W}_{i j}=\left\{\frac{a_{i j}}{c_{i}^{*}}, \frac{b_{i j}}{c_{j}^{*}}, \frac{c_{i j}}{c_{j}^{*}}\right\} \cdot($

$\left.w_{j 1}, w_{j 2}, w_{j 3}\right)=\left\{\frac{a_{i j}}{c_{j}^{*}}, w_{i 1} \frac{b_{i j}}{c_{j}^{*}}, w_{i 2} \frac{c_{i j}}{c_{j}^{*}}, w_{i 3}\right\}$

$\tilde{v}_{i j}=\tilde{r}_{i j}, \widetilde{w}_{i j}=\left\{\frac{a_{j}}{c_{i j}}, \frac{a_{j}}{b_{i j}}, \frac{a_{j}}{a_{i j}}\right\} \cdot($

$\left.w_{j 1}, w_{j 2}, w_{j 3}\right)=\left\{\frac{a_{\bar{j}}}{c_{i j}}, w_{i 1} \frac{a_{\bar{j}}^{\bar{j}}}{b_{j}^{*}}, w_{i 2} \frac{a_{\bar{j}}^{-}}{a_{i j}}, w_{i 3}\right\}$

Equation (5)

The fifth step in this model is to calculate Fuzzy Positive Ideal Solution (FPIS) and Fuzzy Negative Ideal Solution (FNIS). These states are calculated using following equations:

$$
\begin{aligned}
& A^{+}=\left[\tilde{v}_{1}^{*}, \tilde{v}_{2}^{*}, \ldots \tilde{v}_{n}^{*}\right] \\
& A^{-}=\left[\tilde{v}_{1}^{-}, \tilde{v}_{2}^{-}, \ldots, \tilde{v}_{n}^{-}\right]
\end{aligned}
$$

Equation (6)
In these equations, $\tilde{v}_{i}^{*}$ is the best amount of criteria and $\tilde{v}_{i}^{-}$is the worst amount of criteria.

The next step contains calculation of distance of positive and negative ideal which are calculated respectively using the following equations:

$S_{i}^{*}=\sum_{j=1}^{n} d=\left(\tilde{v}_{i j}, v_{j}^{*}\right)$

$S_{i}^{-}=\sum_{j=1}^{n} d=\left(\tilde{v}_{i j}, v_{j}^{-}\right)$

Equation (7)

The last step in this model is calculation of the similarity index which is obtained through following equation:

$$
c c_{i}=\frac{s_{i}^{-}}{s_{i}^{*}+s_{i}^{-}}
$$

Equation (8)

\section{V.FINDING}

Based on the used indices and items for measuring each dimension of spatial effects on space economy revolution in peri - urban of Sanandaj City, the raw data matrix of each criterion in the studied rural areas were collected through questionnaires and then the scores given for questionnaires of each village were replaced by membership function of fuzzy numbers, and then the total fuzzy scores were calculated for each index in each village. This was also done for other criteria in other villages, which results in fuzzy decision making matrix, assessment of spatial effects of Space Economy Revolution in social, economic, physical environmental and infrastructure dimension. After converting weights evaluated by experts into fuzzy triangular numbers, normalization and weighted standard matrix were calculated for the all criteria and variables according to table $4 \& 5$ and chart 1-5. Result this analysis will be presented in the following:

Table4 : Calculation of positive ideal solution and negative ideal solution, similarity index, and ultimate ranks of the research indicators

\begin{tabular}{|c|c|c|c|c|c|c|c|c|c|}
\hline \multicolumn{10}{|c|}{ Spatial Effects in Economic Dimension } \\
\hline Indicator & $\mathbf{D}^{-}$ & $\mathbf{D}^{+}$ & $\mathbf{A}^{*}$ & Ranking & indicator & $\mathbf{D}^{-}$ & $\mathbf{D}^{+}$ & $\mathbf{A}^{*}$ & Ranking \\
\hline E10 & 4.109 & 4.526 & 0.524 & 3 & E1 & 6.688 & 1.526 & 0.186 & 5 \\
\hline E11 & 7.454 & 0.873 & 0.105 & 6 & E2 & 3.305 & 5.34 & 0.618 & 2 \\
\hline E12 & 4.109 & 4.526 & 0.524 & 3 & E3 & 7.454 & 0.873 & 0.105 & 6 \\
\hline E13 & 4.109 & 4.526 & 0.524 & 3 & E4 & 6.688 & 1.526 & 0.186 & 5 \\
\hline E14 & 3.305 & 5.34 & 0.618 & 2 & E5 & 6.688 & 1.526 & 0.186 & 5 \\
\hline E15 & 4.109 & 4.526 & 0.524 & 3 & E6 & 6.688 & 1.526 & 0.186 & 5 \\
\hline E16 & 3.305 & 5.34 & 0.618 & 2 & E7 & 2.775 & 6.173 & 0.69 & 1 \\
\hline E17 & 2.775 & 6.173 & 0.69 & 1 & E8 & 7.454 & 0.873 & 0.105 & 6 \\
\hline E18 & 4.91 & 3.422 & 0.411 & 4 & E9 & 7.454 & 0.873 & 0.105 & 6 \\
\hline
\end{tabular}




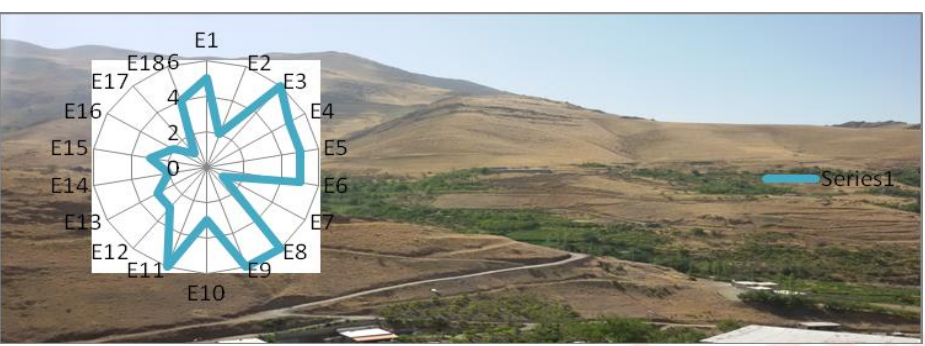

Chart 1: Economic Dimension of the Spatial Effects Ahmadi, 2017

Table 5: Calculation of positive ideal solution and negative ideal solution, similarity index, and ultimate ranks of the research indicators

\begin{tabular}{|c|c|c|c|c|c|c|c|c|c|}
\hline \multicolumn{5}{|c|}{$\begin{array}{l}\text { Spatial Effects in the Physical and } \\
\text { environmental Dimension }\end{array}$} & \multicolumn{5}{|c|}{ Spatial Effects in the Social Dimension } \\
\hline indicator & $\mathrm{D}^{-}$ & D+ & A* & Ranking & indicator & $\mathrm{D}^{-}$ & $\mathrm{D}^{+}$ & $\mathrm{A}^{*}$ & Ranking \\
\hline E34 & 2.790161 & 5.860461 & 0.677 & 2 & E19 & 0.894 & 6.633 & 0.881 & 1 \\
\hline E35 & 1.987461 & 6.863672 & 0.775 & 1 & E20 & 6.425 & 0.980 & 0.132 & 5 \\
\hline E36 & 3.958851 & 4.767337 & 0.546 & 3 & E21 & 1.537 & 5.829 & 0.791 & 2 \\
\hline E37 & 3.958851 & 4.767337 & 0.546 & 3 & E22 & 6.425 & 0.980 & 0.132 & 5 \\
\hline $\mathrm{E} 38$ & 5.034878 & 3.474191 & $\mid 0.408$ & 5 & E23 & 1.697 & 5.628 & 0.768 & 3 \\
\hline \begin{tabular}{l|l} 
E39 & 1
\end{tabular} & 1.987461 & \begin{tabular}{|c|}
6.863672 \\
\end{tabular} & 0.775 & 1 & E24 & 1.697 & 5.628 & 0.768 & 3 \\
\hline \begin{tabular}{l|l}
$\mathrm{E} 40$ & 3
\end{tabular} & 3.958851 & \begin{tabular}{|c|c|}
4.767337 \\
\end{tabular} & 0.546 & 3 & E25 & 4.168 & 3.210 & 0.435 & 4 \\
\hline \multicolumn{10}{|c|}{ Spatial Effects in the Infrastructure Dimension (services and manufacturing) } \\
\hline \multicolumn{3}{|c|}{ indicator } & \multicolumn{2}{|c|}{$\mathrm{D}^{+}$} & \multirow{2}{*}{\multicolumn{3}{|c|}{$\mathrm{A}^{*}$}} & \multicolumn{2}{|c|}{ Ranking } \\
\hline E26 & \multicolumn{2}{|c|}{3.81084} & \multicolumn{2}{|c|}{3.47455} & \multirow{2}{*}{\multicolumn{3}{|c|}{$\begin{array}{ll}0.477 \\
0.714\end{array}$}} & \multicolumn{2}{|c|}{2} \\
\hline E27 & \multicolumn{2}{|c|}{2.184605} & \multicolumn{2}{|c|}{5.442656} & & & & \multicolumn{2}{|r|}{1} \\
\hline E28 & \multicolumn{2}{|c|}{2.184605} & \multicolumn{2}{|c|}{5.442656} & \multicolumn{3}{|c|}{$\frac{0.714}{0.714}$} & \multicolumn{2}{|r|}{1} \\
\hline E29 & \multicolumn{2}{|c|}{3.81084} & \multicolumn{2}{|c|}{3.47455} & & \multicolumn{2}{|r|}{2} \\
\hline E30 & 2.18 & 34605 & 5.442 & & \multicolumn{3}{|c|}{$\frac{0.477}{0.714}$} & & 1 \\
\hline E31 & 6.45 & 8522 & 0.873 & & & 0.119 & & & 3 \\
\hline E32 & & 1084 & 3.47 & & & 0.477 & & & 2 \\
\hline $\mathrm{E} 33$ & 2.18 & 34605 & 5.442 & & & 0.714 & & & 1 \\
\hline
\end{tabular}

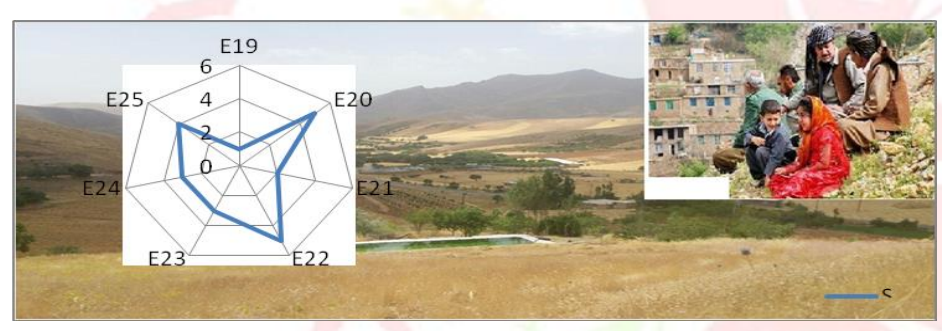

Chart 2: Spatial Effects in the Social Dimension

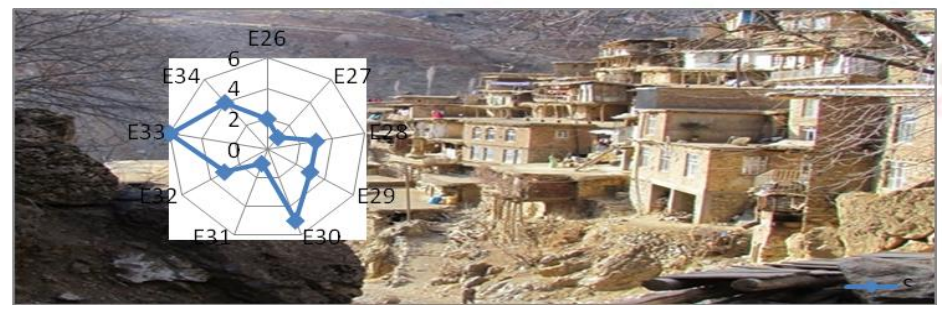

Chart 3: Spatial Effects in the Physical and environmental Dimension

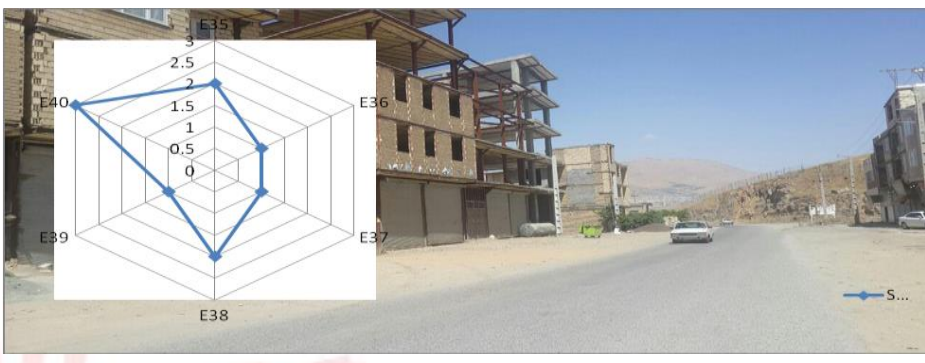

Chart 4: Spatial Effects in the Infrastructure Dimension

\section{Conclusion}

Space and its revolution is actually an objectivity resulting from mutual interactions of individuals and human groups in a place, or in other words, it is the consequence of interactive functions of two natural - ecological and socio - economic environments. Special structure of any place represents interaction between human society and surrounding natural environment (Coates, et al, p: 253). The study and understanding of space systems requires considering the location of functions and interaction between them (Jahnston, $\mathrm{p}, 5)$.

In general, internal and external factors and forces are gradually affecting rural settlements of peripheral villages, so that these changes has been manifested markedly in the social, economic, physical, and spatial structures of these settlements (Saedi and Yamani, 2014: 9). These forces include a set of contributing factors and forces in local, regional and global scale (Saduq and Saedi, 2006).

Therefore, in this study in order to evaluate the spatial effects of Space Economy Revolution, after conducting interviews with experts and academic elite, and designing a researcher made questionnaire, the spatial effects of Space Economy Revolution were identified in peripheral of Sanandaj City.

The results show (Table $4 \& 5$, Chart 1-4), that of the most important effects of Space Economy Revolution in the economic sector include rising land prices, buying and selling land for farming and gardening, reduction in the area under cultivation, increased investment in real estate sector (buy and sell housing). The most important social effects of Space Economy Revolution are rural population growth, increasing rural - urban migration.

The most important physical - environmental effects of Space Economy Revolution in the peripheral villages of Sanandaj include garden and agricultural land conversion to second home, destruction of natural landscapes of villages, and the spread of illegal construction.

And in the infrastructure facilities and services, the effects of Space Economy Revolution in the peripheral villages of 
Sanandaj include improving infrastructure of services, improving access to communication services (telephones, ICT databases, ...), Development of financial services such as Post Bank and Corporations.

\section{References}

[1]. Ahmadi et al, (2011), Tourists optimal path-finding by GIS (Case study: historical texture of Sanandaj), 5 th Symposium on Advances in Science \& Technology, 5thSASTech 12-17 May, 2011. Mashhad-Iran

[2]. Ahmadi, A., 2017, explain Evolution space economy peripheral area of Sanandaj, Ph.D thesis Geography and Rural Planning, Supervisors: Doctor Mohammad Taqi Rahnamee \& Hassan Afrakhteh, Tehran Khrazmi University

[3]. Ataee, M. (2011), Multi - criteria fuzzy decision making, Publication of Shahrood Industrial University

[4]. Afrakhteh, H., 2012, Space Economy in Rural Development (area: Shaft), Journal - space Economy Research, Tehran Khrazmi University

[5]. Saidi, A., Hosseini Hasel, S., 2007, the integration of urban and surrounding rural settlements with a view to metropolitan Tehran, Journal - Research of Geographical Society's, the fifth year No. 12 and 13.

[6]. Saidi, A., 2010, the environment, space and development, a discussion on the need for integrated development of rural - urban, Journal - of housing, the environment and rural, 131 number.

[7]. Nazarian, A., 2009, dynamics of the urban system in Iran, innovators Publishing, first Printing, Tehran

[8]. Shakuie, H, 2003, environmental philosophy and schools of geographical, Gita Press, Tehran

[9]. Piran, p, 1991, the political economy of space, Journal of Economics - political, fifth year; (25).

[10]. Saidi, A., Imani, B., 2014, Role of internal and external factors and forces in process of transformation physical - Space rural settlements around city of Ardabil, Journal - Research Association geography, Issue 40.

[11]. Saidi, A, Saduq, H, 2006, space systems as core of geographical studies, geography, numbers 10

[12]. Statistical Center of Iran, 2011, Yearbook, the city of Sanandaj, first edition, published by the Statistical Center of Iran, Tehran.

[13]. Cohen, G, 1978, Karel Marx's Theory oh history, Oxford, Oxford university press

[14]. Coates, B.E., R.J. Johnston \& P.L. Knox (1977), Geography and Inequality Oxford University Press;

[15]. Johnston,R.J. (1973), Spatial Structures, London;
[16]. Jonston , Ronald John (2000), The dictionary of human geography, Malden, MA, Blackweel, publisher 